was involved in the steroid-stimulating action of ACTH and its second messenger cAMP, influencing mitochondrial cholesterol uptake and cholesterol side-chain cleavage enzyme activity. Calmodulin-induced phosphorylation of certain acceptors in adrenocortical mitochondrial fragments was observed by Bristow et al. [10].

All these data together suggest that calmodulin plays a role in the control of adrenocortical steroidogenesis. Since the stimulation with db-cAMP was less sensitive to the inhibitory action of these drugs than that of angiotensin II, it may be presumed that the mechanism of calmodulin action differs in the case of stimuli acting via calcium signal from those activating the cAMP system.

Acknowledgements-We express our thanks to NIAMDD (Bethesda, MD) for aldosterone antiserum, to Dr H. Green (Smith Kline \& French Laboratories, PA) for trifluoperazine and to Dr W. van Bever (Jansen Pharmaceutica, Beerse, Belgium) for penfluridol and pimozide. We are indebted for the access to a Wang 2200 computer to Dr L. Kiss (Department of Chemical Technology, Technical University, Budapest, Hungary). The skilful technical assistance of Mrs Katalin Maller and Miss Mária Hódosi is gratefully acknowledged.

* To whom correspondence should be addressed.
Department of Physiology

TAMÁS BALLA

Semmelweis University

Medical School

Budapest P.O.B. 259

H-1444 Hungary

\section{REFERENCES}

1. H. Rassmussen, Calcium and cAMP as Synarchic Messengers, p. 235. John Wiley, New York (1981)

2. C. B. Klee, T. H. Crouch and P. G. Richman, A. Rev. Biochem. 49, 489 (1980).

3. T. Balla, L. Hunyady and A. Spät, Biochem. Pharmac. 31, 1267 (1982).

4. B. Weiss, W. Provialeck, M. Cimino, M. S. Bernette and T. L. Wallace, Ann. N.Y. Acad. Sci. 356, 319 (1980).

5. P. Enyedi and A. Spät, J. Endocr. 89, 417 (1981).

6. R. C. Schatzman, B. C. Wise and J. F. Kuo, Biochem. biophys. Res. Commun. 98, 669 (1981).

7. D. J. Campbell, F. A. O. Mendelsohn, W. R. Adam and J. W. Funder, Endocrinology 109, 1484 (1980).

8. J. F. Harper, W. Y. Cheung, R. W. Wallace, H. L. Huang, S. N. Lavine and A. L. Steiner, Proc. natn. Acad. Sci. U.S.A. 77, 366 (1980)

9. P. F. Hall, S. Osawa and C. L. Thomasson, J. Cell Biol. 90, 402 (1981).

10. A. F. Bristow, D. Schulster and R. Rodnight, Biochim. biophys. Acta 675, 24 (1981).

\title{
Time and dose dependence of 3-methylcholanthrene-induced metabolism in rat intestinal mucosal cells and microsomes
}

(Received 24 February 1982; accepted 29 June 1982)

Oxidative drug metabolism activity in the intestinal mucosa is considerably less than in the liver $[1,2]$. It is, however, easily inducible by a variety of compounds present in cigarette smoke and certain foods [3-5]. After induction intestinal monooxygenase activity becomes of quantitative importance as was recently shown by Klippert et al. [6] in our department. They demonstrated an intestinal first-pass deethylation of phenacetin in rats after induction with 3 methylcholanthrene (3-MC)*.

In order to estimate the in vivo activity of intestinal monooxygenase, several systems including everted sacs $[7,8]$, isolated mucosal cells $[9-11]$, homogenates [3] and microsomal fractions $[12,13]$ thereof have been used.

Activity observed in these systems may differ due to variations in the availability of cofactors and diffusion barriers for substrates or their metabolities. Moreover, the inducers and their metabolites may accumulate in cells and/or may interfere with cell wall integrity or biochemical processes which are needed for maintenance of monooxygenase activity.

We studied the time course of induction by $3-\mathrm{MC}$ and Arochlor 1254. It appears that considerable differences occur in both the magnitude and time course of the induc-

* Abbreviations: 3-MC, 3-methylcholanthrene; 7-EC, 7-ethoxycoumarin; 7-HC, 7-hydroxycoumarin; LDH, lactate dehydrogenase. tion between cells and microsomes, which can be explained by toxic effects of the inducing agent 3-MC in cells.

Materials and methods. Adult male Wistar rats weighing approximately $250 \mathrm{~g}$ (TNO, Zeist, The Netherlands) were used. Pretreated animals received a single intragastric injection of $1.0 \mathrm{ml}$ corn-oil or $3-\mathrm{MC}, 5-20 \mathrm{mg} / \mathrm{kg}$ body weight, in $1.0 \mathrm{ml}$ corn-oil by stomach tube, 24 or $48 \mathrm{hr}$ before preparation of cells and/or microsomes. Arochlor $1254,50-200 \mathrm{mg} / \mathrm{kg}$, was administered in the same manner. After treatment rats were allowed free access to food and drinking water.

Preparation of intestinal mucosal cells was basically the same as described by Hülsmann et al. $[14,15]$. The gut was divided into four $15-\mathrm{cm}$ lengths, everted on metal rods, attached with surgical silk and exposed to longitudinal vibration ( $100 \mathrm{~Hz}, 2-\mathrm{mm}$ amplitude) using a Vibro-Mixer (Chemap AG, Mannedorf, Switzerland). Isolated cells were suspended in ice-cold Krebs-Ringer medium saturated with carbogen gas, $\mathrm{pH} 7.4$. Microsomes were prepared from isolated mucosal cells as described by Shirkey et al. [16] using an Ultra-Turrax (Janke \& Kunkel KG, Staufeni, Breisgau) as the homogenizing apparatus. Cell viability was measured by $\mathrm{LDH}$ leakage from the cell cytoplasm into the medium and at least $2 \mathrm{hr}$ after isolation was still between 80 and $90 \%$ [10].

The $O$-dealkylation of 7 -EC was determined according to Greenlee and Poland [17]. Conjugated 7-HC was deter- 
Table 1. Influence of oral pretreatment of rats with different doses of 3-MC or Arochlor 1254 on several characteristics of intestinal mucosal cells isolated with the vibration procedure

\begin{tabular}{|c|c|c|c|c|c|c|}
\hline Inductor & $\begin{array}{c}\text { Dose } \\
(\mathrm{mg} / \mathrm{kg})\end{array}$ & $\begin{array}{c}\text { Cell yield } \\
\left(10^{7}: \mathrm{g} \text { intestine }\right)\end{array}$ & $\begin{array}{l}\text { Viabili } \\
24 \mathrm{hr}\end{array}$ & $\begin{array}{l}\left(\begin{array}{l}0 \\
0\end{array}\right) \\
48 \mathrm{hr}\end{array}$ & \multicolumn{2}{|c|}{$\begin{array}{l}\text { Microsomal P-450 } \\
(\text { pmol } / \mathrm{mg} \text { protein) } \\
24 \mathrm{hr} \\
48 \mathrm{hr}\end{array}$} \\
\hline $\begin{array}{l}3-M C \text {, } \\
\text { Arochlor }\end{array}$ & 0 & $\begin{array}{c}4.5 \\
{[4.4-10.8]}\end{array}$ & $\begin{array}{c}90.9 \\
{[87-99]}\end{array}$ & $\begin{array}{c}88.7 \\
{[86-93]}\end{array}$ & 32 & 33.5 \\
\hline \multirow[t]{4}{*}{$3-M C$} & 5 & {$\left[\begin{array}{c}5.4 \\
{[3.7-7.7]}\end{array}\right.$} & $\begin{array}{c}82.1 \\
{[80-86.5]}\end{array}$ & $\begin{array}{c}83.9 \\
{[75-88]}\end{array}$ & 47.7 & 89.2 \\
\hline & 10 & $\begin{array}{c}7.7 \\
{[3.0-10.2]}\end{array}$ & $\begin{array}{c}88.1 \\
{[84-94]}\end{array}$ & $\begin{array}{c}90.3 \\
{[88-93]}\end{array}$ & 84.2 & 88.3 \\
\hline & 20 & $\begin{array}{c}6.6 \\
{[4.6-9.4]}\end{array}$ & $\begin{array}{c}83 \\
{[80-84]}\end{array}$ & $\begin{array}{c}87.6 \\
{[85-90.5]}\end{array}$ & 143.7 & 113.3 \\
\hline & $2 \times 20$ & $\begin{array}{c}4.2 \\
{[3.0-5.3]}\end{array}$ & $\begin{array}{c}82.5 \\
{[77.8-87.5]}\end{array}$ & -- & 174 & - \\
\hline \multirow[t]{3}{*}{$\begin{array}{l}\text { Arochlor } \\
1254\end{array}$} & 50 & $\begin{array}{c}6.4 \\
{[5.9-6.9]}\end{array}$ & $\begin{array}{c}84 \\
{[80.5-85]}\end{array}$ & $\begin{array}{c}75.5 \\
{[75-76]}\end{array}$ & 58.9 & 34 \\
\hline & 100 & $\begin{array}{c}6.3 \\
{[3.4-7.4]}\end{array}$ & $\begin{array}{c}83 \\
{[78-85]}\end{array}$ & $\begin{array}{c}86.5 \\
{[83-92.5]}\end{array}$ & 98 & 54 \\
\hline & 200 & {$\left[\begin{array}{c}7.0 \\
{[6.0-8.3]}\end{array}\right.$} & $\begin{array}{c}87.5 \\
{[84-92]}\end{array}$ & $\begin{array}{c}86 \\
{[82-90.5]}\end{array}$ & 144 & 107 \\
\hline
\end{tabular}

Cell yield was estimated by suspending an aliquot of cells $(0.1 \mathrm{ml})$ in $0.9 \mathrm{ml}$ of a solution containing $0.16 \%$ trypan blue and $3 \mathrm{mM}$ sodium tetraphenylborate. Cell viability was determined as described in the text, for each rat separately. Lowest and highest values found in at least six different preparations are given in brackets. Microsomal P-450 levels are from one experiment as a typical example of three similar experiments. Four rats per dose were used, and all microsomes were prepared on the same day.

* Viability is expressed as 100 minus percentage of LDH-leaking cells.

mined by a 48 -hr incubation of $1.5 \mathrm{ml}$ aqueous supernatant after chloroform extraction with $1.5 \mathrm{ml}$ acetate buffer $(0.1 \mathrm{M}, \mathrm{pH} 5)$ containing $6000 \mathrm{FU} \beta$-glucuronidase/ arylsulphatase.

Cytochrome P-450 was estimated by means of a dithionite difference spectrum [18]. An Aminco DW-2 UV-Vis spectrophotometer was used. $\mathrm{LDH}$ was assayed using NADH-NAD conversion [10], while overall protein was determined according to Lowry et al. [19].

Results and discussion. A single oral pretreatment with 3-MC in corn-oil at different doses resulted in data shown in Table 1. Pretreatment with 3-MC did not interfere with cell yield as compared with controls. No significant differences were found in cell viability, tested by LDH leakage, for intestinal mucosal cells with respect to dosage of 3-MC or time after oral 3-MC administration ( 24 or $48 \mathrm{hr}$ ). However, cells prepared from control rats tended to have somewhat higher viabilities $(>90 \%)$, while 3-MC-pretreated rats' intestinal cells showed viabilities between 80 and $90 \%$.

Cytochrome P-450 levels in control rats are similar to values between 20 and 50 pmoles $/ \mathrm{mg}$ microsomal protein found by several other authors $[12,20]$ in rat small intestinal mucosa. 3-MC pretreatment resulted in enhanced intestinal microsomal cytochrome P-450 levels (maximum shifted to $448 \mathrm{~nm}$ ) as indicated in Table 1. As compared with control rats (oil, $24 \mathrm{hr}$ ) the cytochrome P-450 content was raised three- to four-fold by $20 \mathrm{mg} / \mathrm{kg} 3-\mathrm{MC}$ within $24 \mathrm{hr}$ after administration. This cytochrome $\mathrm{P}-450$ induction resulted in an even greater enhancement of 7-EC O-deethylation. In Fig. 1(a) and (b) the results for cells and microsomes prepared from the same cell batches for different dosages and times after pretreatment are shown. Microsomal $O$ deethylation was stimulated 20 -fold within $48 \mathrm{hr}$ after 3 -
MC administration, while whole mucosal cells had their maximum [1100-3000 pmoles $\cdot \mathrm{min}^{-1} \cdot \mathrm{g}$ intestine $\left.{ }^{-1}\right]$ at 10 - to 22 -fold their control level $\left[160 \pm 40\right.$ pmoles $\left.\cdot \mathrm{min}^{-1}\right]$ within $24 \mathrm{hr}$. The $O$-deethylation of 7-EC per gram intestine by control rat mucosal cells is twice that of microsomes. consistent with our microsomal yield of $45 \%$. However, after 3-MC induction the ratio cells/microsomes for 7-EC $O$ deethylase activity decreased to $1.0 \pm 0.124 \mathrm{hr}$ after administration and to $0.4 \pm 0.1$ after $48 \mathrm{hr}$. Addition of a $\mathrm{NADPH}$-generating system to cell incubations resulted in a two-fold stimulation for 3-MC-pretreated intestinal cells and had no effect on control cell metabolism (data not shown). These results indicate that the ratio cells/microsomes for cells $48 \mathrm{hr}$ after pretreatment cannot be brought back to 2.0 as for 24-hr cells.

An observation made in all experiments at $48 \mathrm{hr}$ after 3-MC administration was that 7-EC deethylase activity in microsomes (range $1000-2000$ pmoles $\cdot \mathrm{min}^{-1} \cdot \mathrm{g}^{-1}, \mathrm{~N}=10$ ) and $9000 \mathrm{~g}$ supernatant (range $500-2800$ pmoles $\cdot \min ^{-1}$. $\mathrm{g}^{-1}, \mathrm{~N}=4$ ) prepared from intestinal mucosal cells was always significantly higher than deethylase activity in isolated cells of the same batch (range $400-$ 600 pmoles $\cdot \min ^{-1} \cdot g$ intestine ${ }^{-1}, \mathrm{~N}=10$ ). To investigate the nature of this phenomenon several experiments were performed. First of all, the hypothesis that mucosal cells of 3-MC-pretreated rats might be more seriously damaged during vibration was tested. Protein content was determined in the $1000 \mathrm{rpm}$ supernatant after harvesting cells by centrifugation. No significant differences were observed between the intestinal mucosal cell-sup of oil or 3-MCpretreated rats or between cells isolated 24 or $48 \mathrm{hr}$ after pretreatment. Secondly, pretreatment of rats with Arochlor 1254. a mixed-type inducer of P-450 and P-448, was exam- 


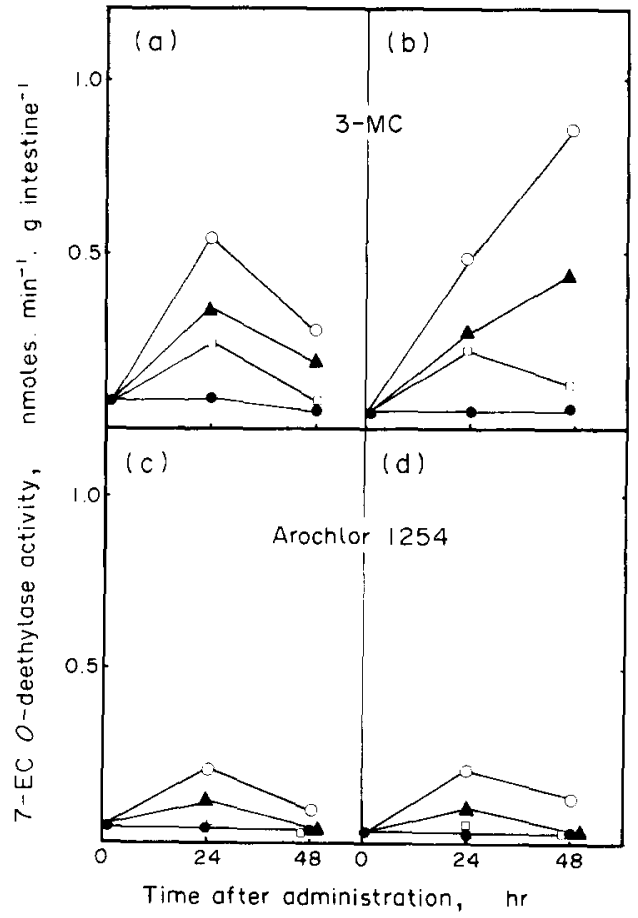

Fig. 1. The effect of oral pretreatment of rats with different doses of 3-MC (upper half: $\boldsymbol{O}$, controls: $\square, \boldsymbol{\Delta}$ and $\bigcirc$ are 5,10 and $20 \mathrm{mg} / \mathrm{kg}$ respectively) or Arochlor 1254 (lower half: $\triangle$, controls; $\square, \Delta$ and $\bigcirc$ are 50,100 and $200 \mathrm{mg} / \mathrm{kg}$ respectively) on 7 -EC $O$-deethylase activity (at $200 \mu \mathrm{M}$ substrate concentration) expressed as 7-HC formed. Deethylation was assayed at $\mathrm{pH} 7.4$ in whole mucosal cells [(a) and (c): $4 \times 10^{6}$ cells $\cdot \mathrm{ml}^{-1} \mathrm{Krebs}-$ Ringer] and in microsomal fractions [(b) and (d): $0.25 \mathrm{mg}$ protein ${ }^{-1}$ in phosphate buffer, $50 \mathrm{mM}$, containing $0.1 \mathrm{mM}$ EDTA] which were prepared immediately from the same cell batches after samples had been taken for viability testing and cell counting. In at least five similar experiments comparable time courses and extents of induction were observed.

ined. Intragastrical administration of Arochlor 1254 in oil, in a 10-fold higher dose range, resulted in a response for 7-EC 0 -deethylation for cells and microsomes of the same batch as presented in Fig. 1(c) and (d). For cell yield $\left[(6.2 \pm 1.2) \times 10^{7}\right.$ cells $\cdot g$ intestine $\left.{ }^{-1}\right]$ and viability $[80$ $90 \%$ ], as summarized in Table 1 , the same observations apply as after 3-MC pretreatment. Cytochrome P-450 induction was largest with $200 \mathrm{mg} / \mathrm{kg}$ at $24 \mathrm{hr}$ after administration (four-fold). At this time the absorption maximum was $449 \mathrm{~nm}$, while after $48 \mathrm{hr}$ the maximum had shifted to $451 \mathrm{~nm}$. 7-EC $O$-deethylase activity in cells and microsomes per gram intestine was about the same for every dose or time interval after Arochlor 1254 administration. As a final experiment, establishing the toxic effect of 3-MC, oral administration of $3-\mathrm{MC}(20 \mathrm{mg} / \mathrm{kg})$ for two consecutive days was tested. The resulting response of cell and microsomal monooxygenase activity was tested and compared with a single administration of 3-MC ( $24 \mathrm{hr})$, using cells prepared on the same day. Results are presented in Fig. 2. An additional 3-MC administration after $24 \mathrm{hr}$ has an adverse effect on cell metabolism which is decreased two-fold per gram intestine while cell yield and viability do not alter significantly (Table 1). Using microsomal preparations of the same cell batches as an alternative in vitro system again we noticed a slightly decreased microsomal conversion of $7-E C$, in spite of a slightly higher cytochrome $\mathrm{P}-450$ level in twice 3-MC-pretreated rats (Table 1). How-



Fig. 2. Time dependence of 7-EC $O$-deethylation in viable intestinal mucosal cells and microsomes isolated from rats $24 \mathrm{hr}$ after a single dose of $3-\mathrm{MC}(20 \mathrm{mg} / \mathrm{kg}, 0)$ or after two 3-MC administrations 48 and $24 \mathrm{hr}$ prior to cell isolation (O). Cells $\left(12 \times 10^{6}\right)$ and microsomes $(0.75 \mathrm{mg}$ protein) were incubated with $200 \mu \mathrm{M}$ 7-EC in a total volume of $3.0 \mathrm{ml}$ and $7-\mathrm{HC}$ was assayed at various times. Each point is the mean value of four to six rats, in two different preparations, the vertical bars indicating the S.D. 7-EC $O$-deethylase activity is expressed as nmoles $7 \cdot \mathrm{HC} \cdot(\mathrm{g}$ intestine) $)^{-1}$ for cells (a) and as nmoles $7-\mathrm{HC} \cdot$ (nmoles P. $450)^{-1}$ in case of microsomal incubations (b). Values for 24-hr 3-MC-pretreated rats studied with cells were significantly different $(\mathrm{P}<0.001)$ from twice 3 -MC-pretreated rats at all time points. Statistical evaluation was performed by use of the Mann-Whitney $U$-test for small numbers [21].

ever, this decrease is not significant as judged by the Mann-Whitney $U$-test. Results are in agreement with those of Stohs et al. [12] using intestinal microsomes. They also compared successive administration of $3-\mathrm{MC}$ for 2 days $(20 \mathrm{mg} / \mathrm{kg})$ and a single dose, resulting in a continual elevation of cytochrome $\mathrm{P}-450$ (448), in contrast to their results for benzo[a]pyrene monooxygenase activity, which declined after a double administration. It is obvious that the turnover rate of the intestinal epithelial cell $(48 \mathrm{hr})$ determines the maximal induction at the same dose. Repeated 3-MC administration can only reduce time variations of induction. A possible disadvantage of frequent 3-MC administration is the accumulation of the strong carcinogen 3-MC in the intestinal wall [22] and toxic effects, resulting in a lower metabolic turnover rate for 7 -EC when using intestinal mucosal cells as an in vitro system.

Conclusions. Using intestinal cells in this study together with $9000 \mathrm{~g}$ supernatant and/or microsomal fractions of cell homogenates, we have indicated a simultaneous inductive and cytotoxic effect of orally administered 3-MC on intestinal mucosal cells. As a result cellular, and probably in vivo, monooxygenase activity, shows a different time course as compared to microsomal activity. Therefore it is recommended that future studies, concerning the induction of the gastrointestinal monooxygenase system, taking 
into account the high cellular turnover rate of the intestinal mucosa, should pay attention to choosing the right $\operatorname{system}(\mathrm{s})$

Department of Pharmacology

Faculty of Pharmacy

State University of Utrecht

Cathariinesingel 60

3511 GH Utrecht

The Netherlands

\section{REFERENCES}

1. R. S. Chabbra, Envir. Hlth Perspect. 33, 61 (1979)

2. H. P. Hoensch and F. Hartmann, Hepatogastroenterology 28, 221 (1981).

3. L. W. Wattenberg, J. L. Leong and P. J. Strand, Cancer Res. 22, 1120 (1962)

4. B. G. Lake, R. Hopkins, J. Chakraborty, J. W. Bridges and D. V. W. Parke, Drug Metab. Dispos. 1, 342 (1973)

5. E. J. Pantuck, K. C. Hsiao, W. D. Loub and L. W. Wattenberg, J. Pharmac. exp. Ther. 198, 278 (1976).

6. P. J. M. Klippert, M. J. J. Littel and J. Noordhoek, submitted for publication.

7. E. Hietanen, Pharmacology 21, 233 (1980)

8. E. J. Pantuck, K. C. Hsiao, S. A. Kaplan, R. Kuntzman and A. H. Conney, J. Pharmac. exp. Ther. 191, 45 (1974).

\footnotetext{
* To whom correspondence should be addressed
}

9. S. J. Stohs, R. C. Grafström, M. D. Burke and S. Orrenius, Archs Biochem. Biophys. 179, 71 (1977).

10. R. Grafström, P. Moldéus, B. Andersson and S. Orrenius, Med. Biol. 57, 287 (1979).

11. R. J. Shirkey, J. Kao, J. R. Fry and J. W. Bridges, Biochem. Pharmac. 28, 1461 (1979).

12. S. J. Stohs, R. C. Grafström, M. D. Burke and S. G. Orrenius, Archs Biochem. Biophys. 117, 105 (1976).

13. R. S. Shirkey, J. Chakraborty and J. W. Bridges, Biochem. Pharmac. 28, 2835 (1979).

14. W. C. Hülsmann, J. W. O. van den Berg and H. R. de Jong, Meth. Enzym. 32, 605 (1973).

15. W. G. J. Iemhoff, J. W. O. van den Berg, A. M. de Pijper and W. C. Hülsmann, Biochim biophys. Acta 215, 229 (1970).

16. R. J. Shirkey, J. Chakraborty and J. W. Bridges, Analyt. Biochem. 93, 73 (1979).

17. W. F. Greenlee and A. Poland, J. Pharmac. exp. Ther. 205, 596 (1978).

18. R. W. Estabrook, J. A. Peterson, J. Baron and A. Hildebrandt, in Methods in Pharmacology (Ed. C. F. Chignell), Vol. 2, p. 303. Appleton-Century-Crofts, New York (1972)

19. O. H. Lowry, N. J. Rosebrough, A. L. Farr and R. J. Randall, J. biol. Chem. 193, 265 (1951).

20. N. G. Zampaglione and G. J. Mannering, J. Pharmac exp. Ther. 185, 1676 (1973)

21. S. Siegel, Nonparametric Statistics for the Behavioral Sciences. McGraw-Hill Kogakusha, Tokyo (1956).

22. E. D. Rees, P. Handelstam and J. Lowry, Fedn Proc. 28, 749 (1969)
$0006-2952 / 82 / 223710-04 \$ 03.00 / 0$ (C) 1982 Pergamon Press Ltd

\title{
Structure-mutagenicity relationships for chlorinated ethylenes: a model based on the stability of the metabolically derived epoxides
}

\author{
(Received 31 March 1982)
}

\begin{abstract}
A number of chlorinated ethylenes are known to be mutagenic in certain bacteria [1], while vinyl chloride, in particular, has been shown to be carcinogenic in laboratory animals [2] and also in humans [3]. It is believed that the genotoxic activity of these compounds depends on the metabolic transformation by monofunctional oxygenases to the corresponding epoxides, the essential feature of which is a three-membered oxirane ring. The chemical reactivity of epoxides towards biological macromolecules such as DNA is well known [4] and depends, in this case, on both the number and distribution of the chlorine atoms in the oxirane ring. Furthermore, there is recent evidence relating DNA binding with mutagenic activity, as shown by Hemminki [5], for example. The detoxification of epoxides, which protects organisms from the deleterious effects of these compounds, is also known to occur. It is controlled mainly by enzymes such as glutathione transferase and epoxide hydrolase. The net genotoxic response of a biological system is a balance between activation (represented by DNA binding) and detoxification (represented by conjugation or diol formation); and this varies with biological species because of the different enzyme levels present
\end{abstract}

Despite the complexity of genotoxic behaviour itself, the activity pattern for a limited series of compounds might be related to certain molecular properties of the compounds in a somewhat less complicated way. Greim et al. [1] have noted a rather simple qualitative relationship between the mutagenicity of a series of chlorinated ethylenes and the molecular symmetry of the related epoxides. The purpose of this investigation is to develop this notion still further by presenting a quantitative structure-activity relationship for the same alkenes based on the calculated electronic structure of the corresponding epoxides, and to use this relationship to predict the mutagenicity of other haloalkenes for which no experimental data exist at present.

Theoretical model for epoxide activity. While the chemical reactions involved in the activation and deactivation of epoxides are quite different, they have one important feature in common; namely, the rupture of the oxirane ring. Given that genotoxic response is a balance between activation and detoxification, it is of interest to explore the possibility that the pattern of mutagenic activity for a series of similar compounds is determined largely by the ease or otherwise of ring opening. Now the rupture of the oxirane 